\title{
Classification of the Juturnaíba Dam: Potential Risk and Damage
}

\author{
Monica de Aquino Galeano da Hora Rocha, Manoel Isidro de Miranda Neto \\ Master's Program in Civil Defense and Security, Fluminense Federal University, Niteroi, Rio de Janeiro, Brazil \\ Email: dahora@vm.uff.br
}

How to cite this paper: de Aquino Galeano da Hora Rocha, M. and de Miranda Neto, M.I. (2018) Classification of the Juturnaíba Dam: Potential Risk and Damage. Journal of Water Resource and Protection, 10, 1-19.

https://doi.org/10.4236/jwarp.2018.101001

Received: December 11, 2017

Accepted: January 22, 2018

Published: January 25, 2018

Copyright () 2018 by authors and Scientific Research Publishing Inc. This work is licensed under the Creative Commons Attribution International License (CC BY 4.0).

http://creativecommons.org/licenses/by/4.0/

\begin{abstract}
A Dam Safety Program aims to reduce the risks to human life, property, and the environment from dam related hazards. In Brazil, despite of the contemporary law about dam safety, there is still no cadastral information nor the classification of risk and associated potential damage to all dams. Besides that, the recent disaster caused by the failure of the Fundão dam, located in Mariana city, Minas Gerais State, is an issue that aggravates the urgency of preventive measures and plans for disaster action. The present study proposes to classify the Juturnaíba dam, which maintains the largest reservoir for water supply in the state of Rio de Janeiro, Southeast region of Brazil. It was sought to analyze the risks and potential damage associated with the dam, in accordance with two classifications: one from the Brazilian Dams Committee and the other from the National Water Resources Council. It was possible to conclude that the Juturnaíba dam potentially presents high risk and associated high rates of damage, both regarding losses of human lives and regarding environmental and socioeconomic impacts. This is mainly due to the poor state of conservation that it currently presents. It is recommended that future studies should assess the slope stability of the earth dam, and that repair work should be implemented on the degraded concrete structures, with recuperation or installation of instruments that would enable monitoring of possible movement of the earth dam.
\end{abstract}

\section{Keywords}

Dam Safety, Disaster, Hydrology

\section{Introduction}

The construction of dams for provisions, electricity supply, flow regulation, waste retention, and other purposes help public authorities meet the needs of 
communities [1].

According to the latest report on dam safety, Brazil has 17,259 dams registered by federal and state regulatory agencies. Of these, 16,313 are exclusively for water retention, 15,671 are for multiple use purposes (e.g., human and industrial supply, irrigation, navigation, animal watering and leisure), and 642 are for hydroelectric power generation. The remaining are dams that contain mining tailings (660) and industrial waste (286) [2].

Water retention dams, when properly designed, constructed and operated, are safe and have low failure probabilities. However, it is inevitable that, despite all precautions, a permanent residual risk exists [3].

[4] consider that the consequences of a possible accident involving water retention dams depend basically on the degree of danger associated with the flood, the degree of exposure and the vulnerability to destruction to which local individuals and assets are subject downstream of the dam.

Currently, there is a strong demand from society to understand the situation of the dams located in their surroundings from the safety perspective and their real risk exposure level from these structures. People are increasingly aware that safety is not an absolute condition but rather that there are risks that must be measured to know whether they are tolerable or not [5].

In this context, the purpose of dam safety programs is to recognize the potential hazards offered by these structures and to reduce them to acceptable levels. Safe dams can be built, and potential deficiencies in safety can usually be corrected before they cause socioeconomic losses, loss of life or ecological disasters [6].

Thus, it is important to act in a preventive manner, particularly in the monitoring and inspection of dams. It should be noted that human, environmental and property losses, such as those of the Fundão dam (Mariana city, Minas Gerais State), are issues that aggravate the urgency of preventive measures and plans for disaster action.

In the state of Rio de Janeiro, the situation is similar: the Juturnaíba dam, which is the largest water reservoir for human consumption in this state, has been exhibiting serious problems in recent years. It is thus imperative that an intervention is made and that there be greater regulation and maintenance control of this structure in the future [7] [8].

Considering this scenario, this paper seeks to analyze the construction process and current conditions of the site and to classify the Juturnaíba dam by risk category and associated potential damage.

\section{Literature Review}

The causes of dam ruptures can be divided into human and natural causes. Among the human causes, there are acts of terrorism and war, errors of design and construction, and operating faults. Natural accidents, however, cause unplanned demand or reduced strength on a dam, causing rupture. Among natural 
accidents, exceptional floods have been observed that result in water levels rising upstream of the dam and overtopping to occur. This event causes a flood more severe than the project design flood or, in the case of dams with controlled spillways, when very high speed of water level rise, spillways are not activated in a timely manner. In the latter case, the issue becomes critical due to the dynamics of decision-making regarding the opening of floodgates, such as occurred at the Euclides da Cunha dam located on the Pardo River in the municipality of São José do Rio Pardo, which ruptured in 1977 due to a delay in action [9].

According to [10] and [11], out of the 5,268 dams built before 1950, 117 of them (2.2\%) ruptured. After 1950, excluding China, out of the total of 12,138 dams built, 59 (0.5\%) ruptured. Most of these ruptures occurred in dams with a height of less than $30 \mathrm{~m}$. According to the authors, most of the ruptures occurred in newly built dams, often in the first 10 years (70\%) and, typically, in the first year of operation.

For concrete dams, foundation problems are the most frequent cause of rupture due to internal erosion (21\%) or low shear strength (21\%). For soil and rockfill dams, the most common cause of rupture is overtopping ( $31 \%$ as the main cause and $18 \%$ as a secondary cause), followed by internal erosion in the body of the dam (15\% as the main cause and $13 \%$ as secondary) and foundation problems ( $12 \%$ as the main cause and $5 \%$ as secondary cause). For masonry dams, the most frequent cause is overtopping (43\%), followed by internal erosion of foundations (29\%) [11].

According to [10], when a failure is related to the auxiliary structures, the most frequent cause is insufficient spillway capacity. In this case, when failure occurs, it is typically abrupt, causing an instantaneous wave, which rapidly increases water levels as it propagates downstream. This is the most likely accident to cause fatalities due to the short time available for warning. As stated by [9], soil or rock dams generally do not withstand overflows because the erosion process causes progressive rupture and cracking, through which the water flows freely.

To minimize the risks involved in dam construction, safety standards used globally, including in Brazil, establish that the design flood should be exceptionally severe as determined using the Probable Maximum Flood (PMF) concept. It is recommended that for a satisfactory safety level, the recurrence interval (RI) associated with the PMF is equal to 10,000 years (i.e., decamillennial) [9].

The criteria for dam classifications vary from country to country. In Brazil, the Brazilian Dam Committee (CBDB) classified dams based on risk potential, size and floods recommended for the design of the spillway, as shown in Tables 1-3.

Enacted September 20, 2010, Law 12.334, which established the National Dams Security Policy (PNSB), provides that dams shall be classified by inspection agents by risk category, associated potential damage, and volume based on general criteria established by the National Council of Water Resources 
Table 1. Classification of the risk potential of dams (Adapted from [9]).

\begin{tabular}{|c|c|c|}
\hline Category & Loss of life & Economic Losses \\
\hline Low & $\begin{array}{l}\text { None expected } \\
\text { (no human housing structure downstream) }\end{array}$ & $\begin{array}{l}\text { Minimum } \\
\text { (undeveloped area and occasional farming structures) }\end{array}$ \\
\hline Significant & $\begin{array}{l}\text { Up to } 5 \\
\text { (no urban development and no more than a small } \\
\text { number of habitable structures downstream) }\end{array}$ & $\begin{array}{l}\text { Appreciable } \\
\text { (farmlands, industries and structures) }\end{array}$ \\
\hline
\end{tabular}

Table 2. Classification of dams by size (Adapted from [9]).

\begin{tabular}{ccc}
\hline Category & Height $(\mathrm{m})$ & Storage $\left(\mathrm{m}^{3}\right)$ \\
\hline Small & $5.0<$ height $<15$ & $0.05 \times 10^{6}<$ volume $<1.0 \times 10^{6}$ \\
Medium & $15<$ height $<30$ & $1.0 \times 10^{6}<$ volume $<50 \times 10^{6}$ \\
Large & height $>30$ & volume $>50 \times 10^{6}$ \\
\hline
\end{tabular}

Table 3. Classification of the dams by spillway design (Adapted from [9]).

\begin{tabular}{ccc}
\hline Risk & Size & Spillway Design Flood \\
\hline \multirow{2}{*}{ Low } & Small & $\mathrm{RI}=50$ to 100 years \\
& Medium & $\mathrm{RI}=100$ to $\frac{1}{2} \mathrm{PMF}$ \\
Large & 0.5 to $1 \mathrm{PMF}$ \\
Small & $\mathrm{RI}=100$ years at $0.5 \mathrm{PMF}$ \\
Medium & Ledium & 0.5 to $1 \mathrm{PMF}$ \\
& Sarge & $1 \mathrm{PMF}$ \\
& Small & 0.5 to $1 \mathrm{PMF}$ \\
& Medium & $1 \mathrm{PMF}$ \\
& Large & $1 \mathrm{PMF}$ \\
\hline
\end{tabular}

(CNRH). All dams intended for the accumulation of water for any use, final or temporary disposal of tailings, and the accumulation of industrial waste and having at least one of the following characteristics are subject to the law: height of dam mass, from the lowest point of the foundation to crest, greater than or equal to $15 \mathrm{~m}$; total reservoir capacity greater than or equal to $3,000,000 \mathrm{~m}^{3}$; container containing hazardous waste; and associated potential damage category rated medium or high [12].

Resolution CNRH 143, dated July 10, 2012, established the general criteria for classification of dams by risk category, associated potential damage and reservoir volume [13].

With regard to risk category (RC), dams are classified according to aspects of the dam that may influence the possibility of an accident and considers the following general criteria: technical characteristics (TC); state of conservation of the dam (SC); and Dam Safety Planning (SP). 
The general criteria used to classify the associated potential damage (APD) in the affected area are: the existence of downstream population with potential loss of human life; the existence of housing units or urban or community facilities; the existence of infrastructure or services; existence of essential public service equipment; the existence of protected areas defined in legislation; nature of waste or stored waste; and the dam's volume.

To classify dams used for water accumulation, the volume of its reservoir is considered: small (volume less than or equal to 5,000,000 $\mathrm{m}^{3}$ ); medium (volume greater than $5,000,000 \mathrm{~m}^{3}$ and less than or equal to $75,000,000 \mathrm{~m}^{3}$ ); large (volume greater than $75,000,000 \mathrm{~m}^{3}$ or equal to $200,000,000 \mathrm{~m}^{3}$ ); and very large (volume greater than $200,000,000 \mathrm{~m}^{3}$ ).

The supervisory agent must then complete the tables in Appendix II of Resolution CNRH 143/2012 and cross-check the information for classification. The RC corresponds to the sum of CT (Table 4), SC (Table 5) and SP (Table 6), which determine the dam risk indicator. In the tables, the numbers in parentheses correspond to the score of the development.

The final result allows the dam to be classified based on the RC, as shown in Table 7.

Table 8 shows the APD score, and Table 9 lists the final classification of the dam according to the score achieved.

\section{Materials and Methods}

\subsection{Region and Site Characterization}

The São João river basin covers an area of $2160 \mathrm{~km}^{2}$ and is fully included in the state of Rio de Janeiro, Southeastern Brazil, as shown in Figure 1. The municipalities included in the basin are Araruama, Cabo Frio, Cachoeiras de Macacu, Casimiro de Abreu, Rio Bonito, Rio das Ostras, São Pedro da Aldeia and Silva Jardim [14].

Table 4. Classification of technical characteristics (Adapted from [13]).

\begin{tabular}{|c|c|c|c|c|c|}
\hline $\begin{array}{l}\text { Height (m) } \\
\quad \text { (a) }\end{array}$ & $\begin{array}{l}\text { Length (m) } \\
\quad(b)\end{array}$ & $\begin{array}{l}\text { Type of Dam by } \\
\text { Construction Material } \\
\text { (c) }\end{array}$ & $\begin{array}{l}\text { Type of Foundation } \\
\text { (d) }\end{array}$ & $\begin{array}{l}\text { Age of Dam } \\
\text { (e) }\end{array}$ & $\begin{array}{l}\text { Design Flow } \\
\text { (f) }\end{array}$ \\
\hline $\begin{array}{l}\text { Height } \leq 15 \\
\quad(0)\end{array}$ & $\begin{array}{c}\text { Length } \leq 200 \\
\text { (2) }\end{array}$ & $\begin{array}{l}\text { Conventional Concrete } \\
\text { (1) }\end{array}$ & $\begin{array}{l}\text { Sound rock } \\
\text { (1) }\end{array}$ & $\begin{array}{l}\text { Between } 30 \text { and } 50 \\
\text { years } \\
\text { (1) }\end{array}$ & $\begin{array}{l}\text { PMF or Decamillennial } \\
\text { (3) }\end{array}$ \\
\hline $\begin{array}{l}15<\text { height }<30 \\
\text { (1) }\end{array}$ & $\begin{array}{l}\text { Length }>200 \\
\text { (3) }\end{array}$ & $\begin{array}{l}\text { Stone masonry/cyclopean } \\
\text { concrete-CCR } \\
\text { (2) }\end{array}$ & $\begin{array}{c}\text { Altered hard rock } \\
\text { with treatment } \\
(2)\end{array}$ & $\begin{array}{c}\text { Between } 10 \text { and } 30 \\
\text { years } \\
(2)\end{array}$ & $\begin{array}{l}\text { Millennial } \\
\quad(5)\end{array}$ \\
\hline $\begin{array}{l}30 \leq \text { Height } \leq 60 \\
\text { (2) }\end{array}$ & - & $\begin{array}{c}\text { Homogeneous } \\
\text { soil/rockfill/soil rockfill } \\
\text { (3) }\end{array}$ & $\begin{array}{l}\text { Untreated altered rock/altered } \\
\text { fractured rock with treatment } \\
\text { (3) }\end{array}$ & $\begin{array}{l}\text { Between } 5 \text { and } 10 \text { years } \\
\text { (3) }\end{array}$ & $\begin{array}{c}\mathrm{RI}=500 \text { years } \\
(8)\end{array}$ \\
\hline $\begin{array}{l}\text { Height }>60 \\
\text { (3) }\end{array}$ & - & (a) & $\begin{array}{l}\text { Soft altered rock/compacted } \\
\text { saprolite soil } \\
(4)\end{array}$ & $\begin{array}{c}<5 \text { years or }>50 \text { years } \\
\text { or no information } \\
(4)\end{array}$ & $\begin{array}{c}\mathrm{RI}<500 \text { years or } \\
\text { unknown/unreliable study } \\
(10)\end{array}$ \\
\hline- & - & - & $\begin{array}{c}\text { Residual soil/alluvium } \\
\text { (5) }\end{array}$ & 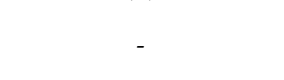 & 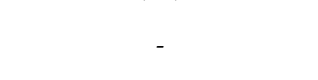 \\
\hline
\end{tabular}


Table 5. Classification of state of conservation (Adapted from [13]).

\begin{tabular}{|c|c|c|c|c|c|}
\hline $\begin{array}{l}\text { Reliability of Overflow Structures } \\
\text { (g) }\end{array}$ & $\begin{array}{l}\text { Reliability of Adduction } \\
\text { Structures } \\
\text { (h) }\end{array}$ & $\begin{array}{l}\text { Percolation } \\
\text { (i) }\end{array}$ & $\begin{array}{l}\text { Deformations and } \\
\text { settling } \\
\text { (j) }\end{array}$ & $\begin{array}{l}\text { Deterioration of } \\
\text { embankments/ } \\
\text { supporting walls } \\
\text { (k) }\end{array}$ & $\begin{array}{l}\text { Locks } \\
\text { (1) }\end{array}$ \\
\hline
\end{tabular}

Civil and hydro-mechanical

structures in full

operation/unobstructed approach or restitution channels or spillway (free-flowing weir)

(0)

Civil and hydro-electromechanical structures prepared for operation, but with no sources of emergency power supply/channels or spillway (free-flowing weir) with erosions or obstructions, but with no risk to the slope structure

(4)

Reliability of Overflow Structures

(g)

Compromised civil structures or hydro-electromechanical devices with Compromised civil identified problems, with reduced structures or flow capacity and corrective measures hydro-electromechanical under implantation/channels or spillway (free-flowing weir) with devices with identified problems, with reduced erosions and/or partially obstructed, flow capacity and no with risk of impairment of the slope corrective measures structure

(6)

(7)

Compromised civil structures or hydro-electromechanical devices with identified problems, with reduced flow capacity and no corrective measures/obstructed channels or spillway (free-flowing weir) or with damaged structures

(10)

\section{Civil structures and} hydro-electromechanical devices under proper conditions of maintenance and operation

(0)

Compromised civil structures or flow capacity and corrective measures under implantation

Reliability of Adduction Structures

(h) hydro-electromechanical stabilized and/or devices with identified monitored

(i) supporting walls, impact embankments or (1) abutments

(3)

Percolation

Deformations and settling

(j)

Existence of small size cracks and

Humidity or upwelling in Existence of cracks downstream areas, and abatements of supporting walls, considerable impact, embankments or generating a need for abutments, additional studies or untreated or in the monitoring diagnostic phase (5) (5)

$\begin{array}{ll}\text { Upwelling in } & \text { Existence of } \\ \text { downstream areas, } & \text { significant cracks, } \\ \text { embankments or } & \begin{array}{l}\text { abatements or } \\ \text { abutments with }\end{array} \\ \text { material bearing or } & \text { potential for } \\ \text { with increasing } & \text { compromising safet } \\ \text { flow } & \text { (8) }\end{array}$

(8)
Gaps in protection Civil and to embankments hydroand supporting electromechanical walls, presence of structures well small shrubs of no maintained and impact functioning (1)

(1)

\section{Deterioration of embankments/ Locks supporting walls}

(k)

\section{Compromised civil}

Surface erosion, structures or exposed hardware, hydrogeneralized electromechanical vegetation growth, devices with generating a need identified problems for monitoring or and corrective meascorrective action ures under implanta(5) tion

(2)

Significant Compromised civil depressions in structures or embankments, hydrolandslides, deep electromechanical erosion grooves, devices with with potential for identified problems compromising and no corrective safety measures (7)

The São João River begins in the Sambê Mountains on the foothills of Serra do Mar at $700 \mathrm{~m}$ of altitude in the municipality of Cachoeiras de Macacu. Its total length of $150 \mathrm{~km}$ travels in the Northeast direction until it drains into the Atlantic Ocean in the city of Barra de São João. The main tributaries to the São João River upstream of the Juturnaíba reservoir are, on the left bank, the Águas Claras, Pirineus, Bananeira and Maratuã Rivers and, on the right bank, the Gaviões, Ouro, Salto d'Água and Cambucas Rivers. The Capivari and Bacaxá Rivers flow 
Table 6. Classification of the dam safety plan (Adapted from [13]).

\begin{tabular}{|c|c|c|c|c|}
\hline $\begin{array}{l}\text { Existence of project } \\
\text { documentation } \\
\text { (n) }\end{array}$ & $\begin{array}{l}\text { Organizational structure and } \\
\text { technical qualification of the Dam } \\
\text { Safety team professionals } \\
\text { (o) }\end{array}$ & $\begin{array}{l}\text { Procedures for safety and } \\
\text { monitoring inspections } \\
\text { (p) }\end{array}$ & $\begin{array}{l}\text { Operational rule } \\
\text { of dam discharge } \\
\text { devices } \\
\text { (q) }\end{array}$ & $\begin{array}{l}\text { Security inspection reports with } \\
\text { analysis and interpretation } \\
\text { (r) }\end{array}$ \\
\hline $\begin{array}{l}\text { Executive and "as-built" } \\
\text { project } \\
(0)\end{array}$ & $\begin{array}{l}\text { It has an organizational structure } \\
\text { with a technician responsible for } \\
\text { dam safety } \\
\text { (0) }\end{array}$ & $\begin{array}{l}\text { It has and applies inspection } \\
\text { and monitoring } \\
\text { procedures } \\
(0)\end{array}$ & $\begin{array}{l}\text { Yes or free-flowing } \\
\text { weir spillway } \\
(0)\end{array}$ & $\begin{array}{l}\text { Reports regularly } \\
(0)\end{array}$ \\
\hline $\begin{array}{l}\text { Executive or "as-built" } \\
\text { project } \\
\text { (2) }\end{array}$ & $\begin{array}{l}\text { It has a technician } \\
\text { responsible for dam safety } \\
\text { (4) }\end{array}$ & $\begin{array}{l}\text { It has and applies only } \\
\text { inspection procedures } \\
\text { (3) }\end{array}$ & $\begin{array}{l}\text { No } \\
(6)\end{array}$ & $\begin{array}{l}\text { It issues reports without } \\
\text { periodicity } \\
\text { (3) }\end{array}$ \\
\hline $\begin{array}{l}\text { Basic project } \\
\text { (4) }\end{array}$ & $\begin{array}{l}\text { It has no organizational structure } \\
\text { and technician responsible for } \\
\text { dam safety } \\
\text { (8) }\end{array}$ & $\begin{array}{l}\text { It has and does not apply } \\
\text { inspection and monitoring } \\
\text { procedures } \\
\text { (5) }\end{array}$ & - & $\begin{array}{l}\text { It does not issue reports } \\
\text { (5) }\end{array}$ \\
\hline
\end{tabular}

Table 7. Classification ranges for risk category (Adapted from [13]).

\begin{tabular}{lcc}
\hline & Risk Category & Score \\
\cline { 2 - 3 } Classification ranges & High & $\geq 60$ or SC $=8\left(^{*}\right)$ \\
& Medium & 35 to 60 \\
& Low & $\leq 35$ \\
\hline
\end{tabular}

${ }^{*}$ ) A score (greater than or equal to 8 ) in any State of Conservation column automatically implies a high-risk category and a need for immediate action by the dam authorities.

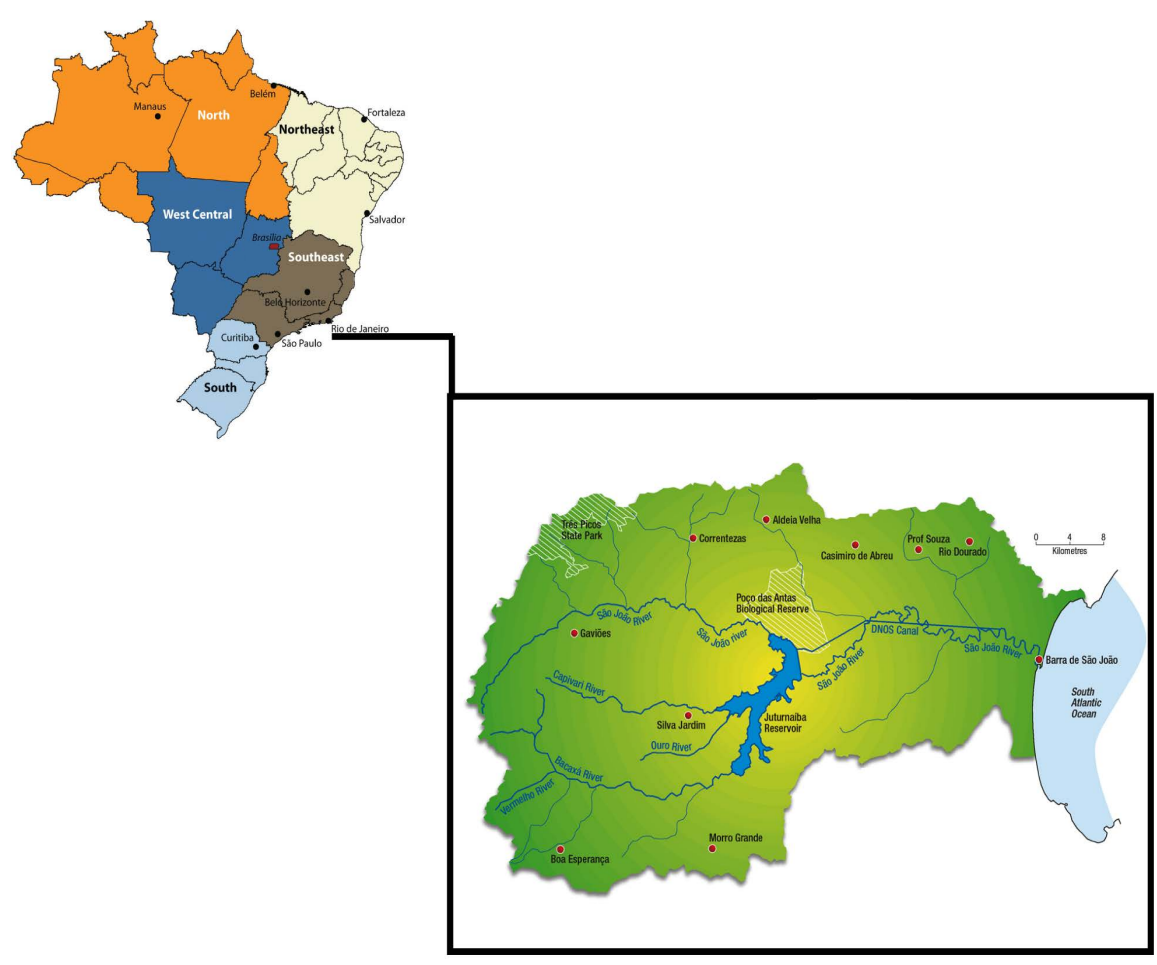

Figure 1. São João river basin (Adapted from [15]). 
Table 8. Classification of associated potential damage (Adapted from [13]).

\begin{tabular}{|c|c|c|c|}
\hline $\begin{array}{l}\text { Total Reservoir Volume } \\
\text { (a) }\end{array}$ & $\begin{array}{l}\text { Potential for loss of human life } \\
\text { (b) }\end{array}$ & $\begin{array}{l}\text { Environmental impact } \\
\text { (c) }\end{array}$ & $\begin{array}{l}\text { Socioeconomic impact } \\
\text { (d) }\end{array}$ \\
\hline $\begin{array}{l}\text { Small } \\
<=5 \text { million } \mathrm{m}^{3} \\
\text { (1) }\end{array}$ & $\begin{array}{l}\text { NONEXISTENT } \\
\text { (there are no permanent/resident or } \\
\text { temporary/transiting persons in the } \\
\text { affected area downstream of the dam) } \\
\text { (0) }\end{array}$ & $\begin{array}{l}\text { SIGNIFICANT } \\
\text { (affected area of the dam does not } \\
\text { represent an area of environmental interest, } \\
\text { areas protected under specific legislation or it } \\
\text { is totally devoid of its natural conditions) } \\
\text { (3) }\end{array}$ & $\begin{array}{l}\text { NONEXISTENT } \\
\text { (there are no facilities and } \\
\text { navigational services in the area } \\
\text { affected by the dam accident) } \\
\text { (0) }\end{array}$ \\
\hline $\begin{array}{l}\text { Medium } \\
5 \text { million to } 75 \\
\text { million } \mathrm{m}^{3} \\
\text { (2) }\end{array}$ & $\begin{array}{l}\text { INFREQUENT } \\
\text { (there are no persons permanently } \\
\text { occupying the affected area } \\
\text { downstream of the dam, but there } \\
\text { is a side road of local use) } \\
\text { (4) }\end{array}$ & $\begin{array}{l}\text { VERY SIGNIFICANT } \\
\text { (affected dam area shows relevant } \\
\text { environmental interest or protected } \\
\text { under specific legislation) } \\
\text { (5) }\end{array}$ & $\begin{array}{l}\text { LOW } \\
\text { (there is a small concentration of } \\
\text { residential and commercial, } \\
\text { agricultural, industrial or } \\
\text { infrastructure facilities in the } \\
\text { affected dam area or port facilities } \\
\text { or navigational services) } \\
\text { (4) }\end{array}$ \\
\hline $\begin{array}{l}\text { Large } \\
75 \text { million to } \\
200 \text { million } \mathrm{m}^{3} \\
\text { (3) }\end{array}$ & $\begin{array}{l}\text { FREQUENT } \\
\text { (there are no persons permanently } \\
\text { occupying the affected area } \\
\text { downstream of the dam, but there is a } \\
\text { municipal, state, federal or other local } \\
\text { highway and/or possible building of } \\
\text { potential permanence of persons } \\
\text { that may be affected) } \\
\text { (8) }\end{array}$ & & $\begin{array}{l}\text { HIGH } \\
\text { (there is a large concentration of } \\
\text { residential and commercial, } \\
\text { agricultural, industrial facilities, } \\
\text { leisure and tourism infrastructure } \\
\text { and services in the affected area of } \\
\text { the dam or port facilities or } \\
\text { navigational services) } \\
\text { (8) }\end{array}$ \\
\hline $\begin{array}{l}\text { Very large } \\
>200 \text { million } \mathrm{m}^{3} \\
\text { (5) }\end{array}$ & $\begin{array}{l}\text { EXISTING } \\
\text { (there are persons permanently } \\
\text { occupying the affected area } \\
\text { downstream of the dam, therefore } \\
\text { human lives may be affected) } \\
\text { (12) }\end{array}$ & - & - \\
\hline
\end{tabular}

Table 9. Classification ranges for the associated potential damage category (Adapted from [13]).

\begin{tabular}{ccc}
\hline & Associated Potential Damage & Score \\
\cline { 2 - 3 } Classification ranges & High & $\geq 16$ \\
& Medium & $10<$ APD $<16$ \\
Low & $\leq 10$ \\
\hline
\end{tabular}

into the reservoir. Downstream of the reservoir, the São João River ranges in slope from $6 \%$ to $1 \%$ in an alluvial plain with large flooded areas, receiving on the right bank the Morto River and on the left bank the Aldeia Velha, Lontra and Dourado Rivers [16].

In the central part of the basin, a lake is formed by the Capivari and Bacaxá rivers discharging into the São João River. This region is characterized as a valley bottom filled with sediments of fluvial and fluviolacustrine origins with deposits of peaty black clays of varying thickness, reaching up to $10 \mathrm{~m}$. Originally, the lake had a water surface area of $5.6 \mathrm{~km}^{2}$ with a volume of 10 million $\mathrm{m}^{3}$, an al- 
most rectangular shape, and a mean depth of approximately $4 \mathrm{~m}$ [17].

It is noteworthy that the São João River basin is an Atlantic Forest conservation unit, called the APA of the São João/Mico-Leão-Dourado River Basin. In addition, the Poço das Antas Rebio is downstream of the dam [18].

As stated by [17], the damwas designed in 1972 by the Ministry of Interior, and the National Department of Sanitation Works (DNOS) was responsible for the management and supervision of the site. Initially, the dam was designed to accumulate water for the domestic and industrial supply of the Lagos Region to control the floods in the São João River and to provide water to irrigate the areas downstream of the dam. The work began in January 1979 and was completed in 1984. According to [15], the dam is located at $22^{\circ} 35^{\prime} \mathrm{S}$ and $42^{\circ} 16^{\prime} \mathrm{W}$.

The main physical and hydraulic characteristics of the dam and civil structures are listed in Table 10.

According to [17], the left abutment of the dam is supported by the Crioulas Hill, while the right abutment is supported by the Madureira Hill. Downstream of the spillway a structural concrete bridge of $180 \mathrm{~m}$ was built, serving as a connection between the São João River's banks.

Table 10. Data sheet of the dam and civil structures (Adapted from [17] [19] [20] [21]; [22] and [23]).

\begin{tabular}{|c|c|}
\hline \multicolumn{2}{|c|}{ RESERVOIR $^{(19)}$} \\
\hline Maximum volume & $78.51 \times 106 \mathrm{~m}^{3}$ \\
\hline Maximum water level & $11.40 \mathrm{~m}$ \\
\hline \multicolumn{2}{|c|}{$\mathrm{DAM}^{(20)}$} \\
\hline Type & Earth dam \\
\hline Length & $3460 \mathrm{~m}$ \\
\hline Crest elevation & $12.00 \mathrm{~m}$ \\
\hline \multicolumn{2}{|c|}{ SPILLWAY ${ }^{(21) ;(17)}$} \\
\hline Type & Labyrinth with 4 elements ${ }^{(21)}$ \\
\hline Total width & $163.5 \mathrm{~m}^{(21)}$ \\
\hline Total development & $710 \mathrm{~m}^{(17)}$ \\
\hline Crest elevation & $8.40 \mathrm{~m}^{(21)}$ \\
\hline Bottom elevation & $3.00 \mathrm{~m}^{(21)}$ \\
\hline Height & $5.40 \mathrm{~m}^{(21)}$ \\
\hline Maximum water level on crest (NAmax max) & $11.40 \mathrm{~m}^{(21)}$ \\
\hline Flow corresponding to maximum water level (Q) & $5600 \mathrm{~m}^{3} / \mathrm{s}^{(21)}$ \\
\hline \multicolumn{2}{|c|}{ SLUICES WITH STOP-LOG FLOODGATES ${ }^{(22) ;(23)}$} \\
\hline Right side of spillway & 4 units $^{(23)}$ \\
\hline Left side of spillway & 4 units $^{(23)}$ \\
\hline Width of each unit & $1.20 \mathrm{~m}^{(23)}$ \\
\hline Height of each unit & $1.20 \mathrm{~m}^{(23)}$ \\
\hline Minimum operating water level & $3.00 \mathrm{~m}^{(22)}$ \\
\hline Maximum operating water level & $8.60 \mathrm{~m}^{(22)}$ \\
\hline
\end{tabular}




\subsection{Construction Aspects}

On August 15, 1975, a technical team from the now-closed DNOS made up of engineers and geologists explored the site of the future Juturnaiba dam project to investigate the conditions of local foundations and concluded that the soil was peaty with layers of clay from soft to very soft. Given the differentiated foundation conditions along the axis, typical sections were proposed per stretch [20], as shown in Figure 2.

Section I is $1300 \mathrm{~m}$ long and extends from the left abutment to Crioulas Island. Because the local foundation is in sand, it was suggested that a sealing trench wall be dug. However, during excavation, pockets of soft clay were found. For this reason, the design was modified, and the geometry of the dam section was modified with the slopes of upstream and downstream embankments of 2.5 $(\mathrm{H}): 1.0(\mathrm{~V})$. The crest of the dam was fixed at an elevation of $12.0 \mathrm{~m}$ with a width of $10 \mathrm{~m}$. The construction of this section began in June 1979 and ended in January 1980. Due to the presented behavior, there was no need to install instrumentation [20].

Section II is located between the right abutment and pile 35 and has an upstream embankment composed of a $45 \mathrm{~m}$ berm at an approximate elevation of $5.5 \mathrm{~m}$, followed by an embankment with $4.0(\mathrm{H}): 1.0$ (V) slope to the dam top elevation. The crest is $14 \mathrm{~m}$ wide, and the downstream embankment has a 3.0 (H):1.0 (V) slope to the elevation of $7.5 \mathrm{~m}$, followed by berms at the $7.5 \mathrm{~m}, 6.5 \mathrm{~m}$ and $5.5 \mathrm{~m}$ elevations, respectively, with 30,20 and 17 meters in length. Construction began in May 1981 and required the removal of the foundation, which had a variable thickness of 3 to $4 \mathrm{~m}$ from the beginning of the upstream berm up to the downstream berm at the $7.5 \mathrm{~m}$ elevation [24].

According to [20], Section III is 1,480 $\mathrm{m}$ in length and extends from Madureira Island to pile 40. Based on the results of the surveys, the section was subdivided into sections III-1 and III-2. The first, which had its foundation in sand, has a section with $3.0(\mathrm{H}): 1.0(\mathrm{~V})$ slopes and began construction in November 1979 and ended construction in August 1980. In Section III-2, which had the

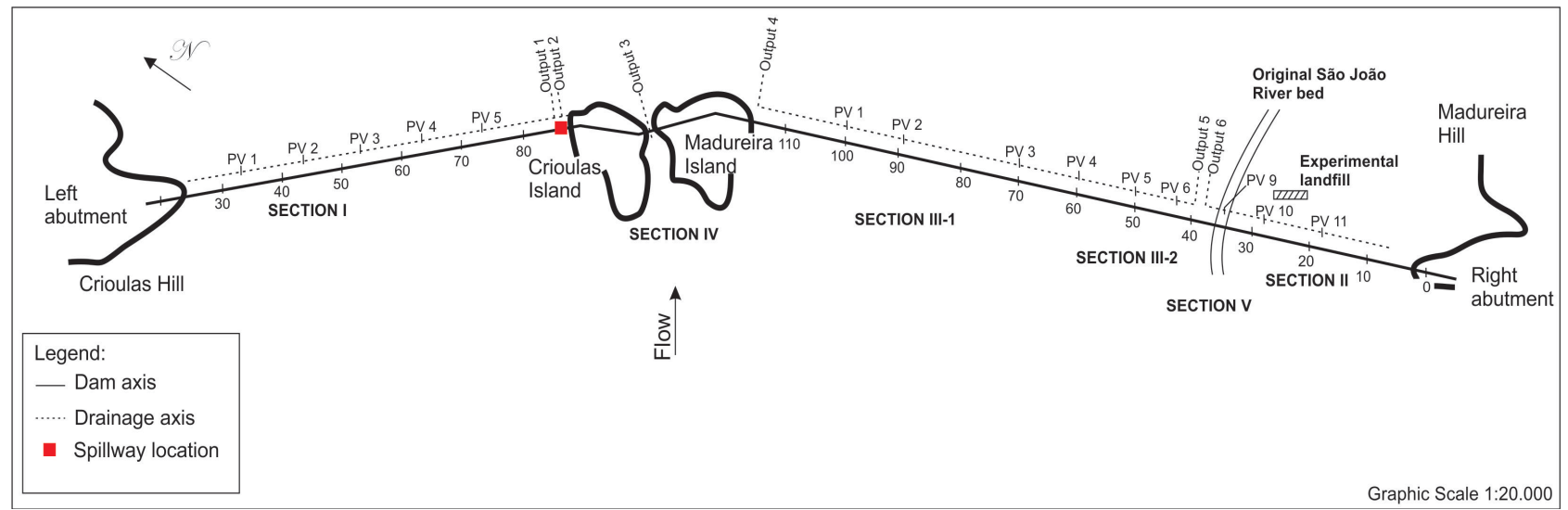

Figure 2. Axis of the Juturnaíba Dam, showing the location of the piles on the São João river bed, including inspection wells and outputs of the well drains (Adapted from [20]). 
same typical section as Section II, a study of the behavior of organic soils/soft clay was performed through the construction and rupture of an experimental landfill, built from February to April of 1980, which supported the study developed by [25]; this was required due to precarious foundation conditions caused by the soft clay layer, which ranged between 7 and $10 \mathrm{~m}$ in thickness.

The excavation of Section IV's foundations, which were located between the two islands, also began in May 1981. All soft material composed of peat and soft clay was removed, reaching a foundation in sands. Construction of this section continued normally, achieving the crest at the $12.0 \mathrm{~m}$ elevation in November $1981[20]$.

Construction of Section V, which is located between piles 35 and 40, began in June 1982. An important detail was the execution of the drainage at the foot of the dam. Due to the possibility of a flood in the summer, it was decided in December 1982 to raise the dam in Section V up to $9.0 \mathrm{~m}$ in elevation. In February 1983 , it was then decided to raise Section $V$ with maximum increments of $50 \mathrm{~cm}$ of landfill in 3 days. At that time, the foundation settlings of Section $\mathrm{V}$ had reached 60 to $70 \mathrm{~cm}$. A similar decision was made for Sections III-2 and II, when settling was found to range from 70 to $90 \mathrm{~cm}$. Due to the scarcity of financial resources, construction took 5 years [20].

With regard to the design and construction of the Juturnaíba spillway, no documents related to the calculation worksheets of the design flow sizing were found. The only available document found was the drawing titled "Zigzag Spillway Model-Plant-Sections-Details" [21]. In the drawing, detail "1" shows the cross-section of the spillway, in which only the design flow of $5600 \mathrm{~m}^{3} / \mathrm{s}$ is identified without an associated recurrence interval. Thus, to evaluate the damping of this flood and its lamination through the spillway, [26] estimated the PMF and found the figure of $5587 \mathrm{~m}^{3} / \mathrm{s}$, showing that the DNOS design flow is compatible with the 10,000-year flood; thus, the Juturnaíba spillway was dimensioned according to dam safety criteria. Figure 3 shows a reproduction of detail "1" from the original DNOS plant.

\subsection{Current Site Situation}

To understand the current situation of the site, a visit to the reservoir and Juturnaíba dam was conducted on January 13, 2016 with technical assistance from the Rio de Janeiro State Agency for the Environment (SEA).

Access to the dam allows the option for two different paths on a dirt road: one that leads to the crest, and another that leads to the foot of the dam. We decided to visit the crest of the dam. Along this access road, state agency signs can be seen, prohibiting the entry of vehicles and unauthorized persons, as well as the presence of barriers that prevent the passage of larger vehicles, such as trucks and tractors.

During the inspection, agricultural activities were visible in the area surrounding the lake. When crossing the ridge, the undesired presence of animals was observed, especially cattle and termites. Inspection wells were also observed, 


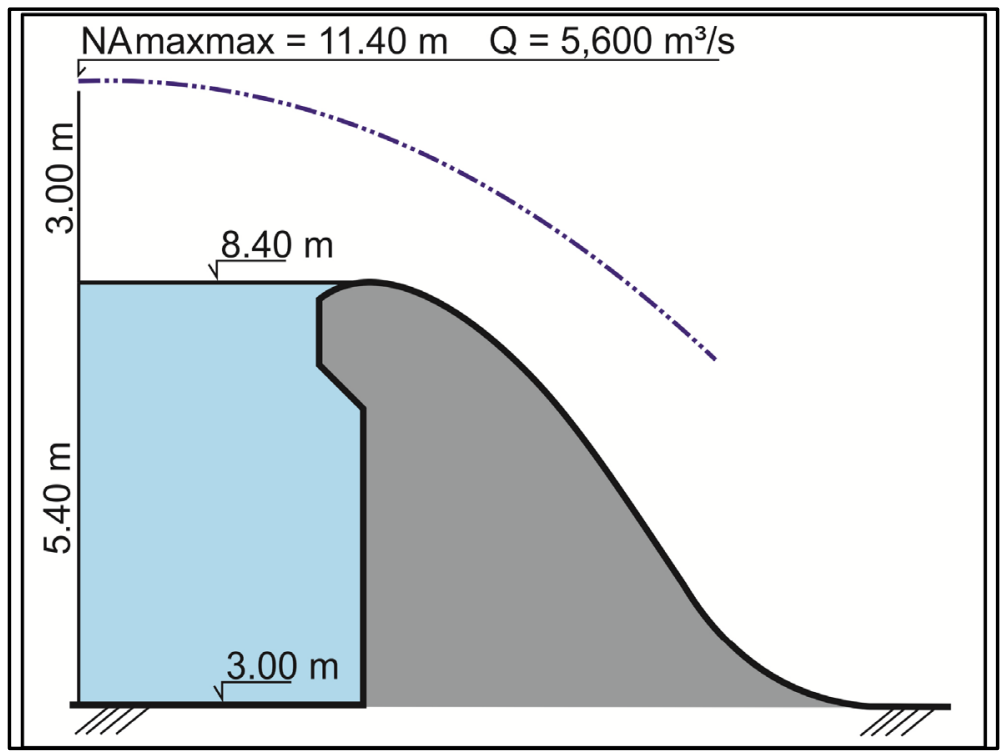

Figure 3. Diagram of the cross-section of the spillway ([26] adapted from $[21])$.

some near the foot of the dam and others in the downstream embankment. Some of the covers in these inspection wells were found to be damaged by rust, while others did not have covers. Given the dangerous conditions, it was not possible to inspect the interior of the wells, Figure 4.

Following a dirt road, we arrived at the site of the hydraulic structures of the dam after passing Crioulas Island. The dam has a labyrinth spillway with 4 cycles and 8 sluices, 4 on each side. It was observed that each side of the spillway also has a concrete channel. This complementary structure would allow the construction of channels adjacent to the São João River, which would lead outflow water for irrigation of local agriculture. However, the irrigation channels do not exist.

The hydraulic structures on the right side of the spillway are damaged, as shown in Figure 5. The structure of the restitution channel on the right side had collapsed; broken concrete blocks were visible. Vegetation was also found where the complementary channel should be. In addition, four sluices were found to be closed by their respective floodgates; however, water still flowed downstream, indicating poor sealing.

The walls of the restitution channel on the left side of the spillway were also found to be collapsed, as shown in Figure 6 and Figure 7.

The structure was also found to be collapsing downstream of the dam. A large concrete block has already broken off and is now in the São João River just downstream of the spillway. If there is no adequate restoration of the structure, there will probably be a final separation of this main channel from the dam body and damage to the complementary structure for the irrigation channels. Another important observation is that only the left-side floodgates are in operation. During the visit, water flowing through the rightmost floodgate was observed, as shown in Figure 8. 


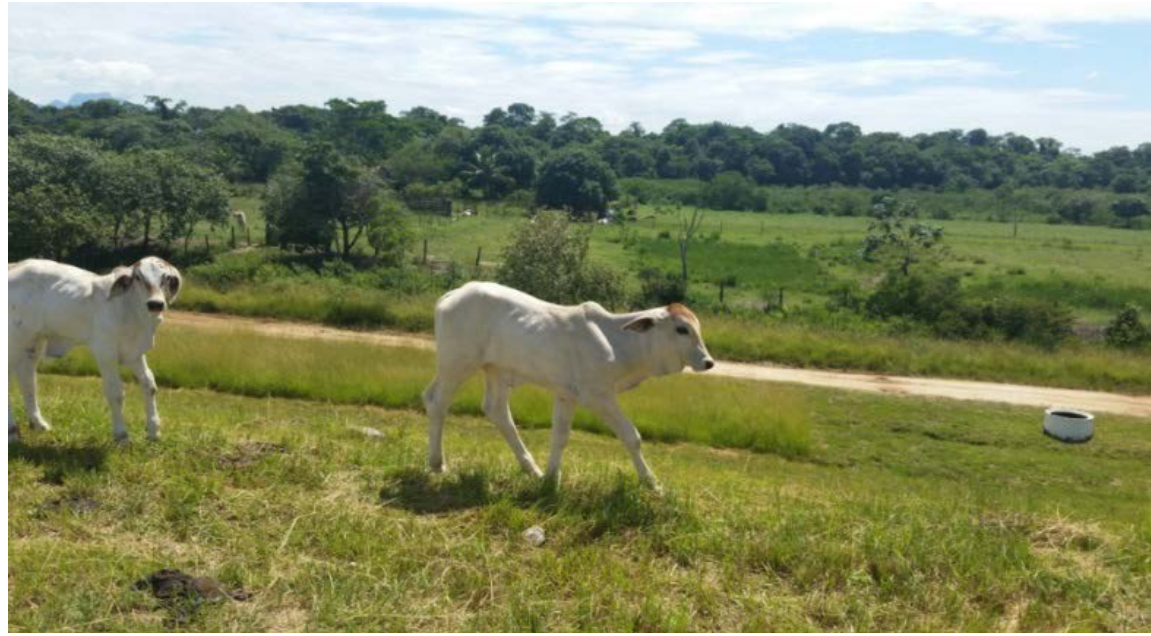

Figure 4. Cattle circulating freely on the crest of the dam near an inspection well without a cover [26].

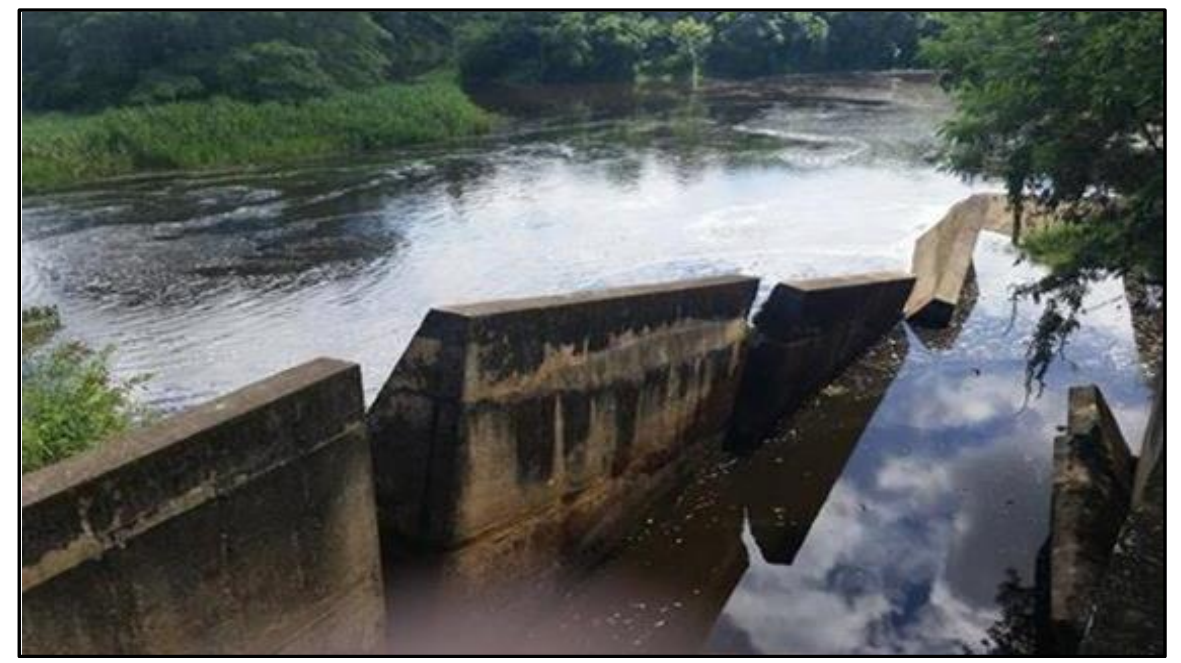

Figure 5. Broken concrete structure on the right side of the spillway [26].

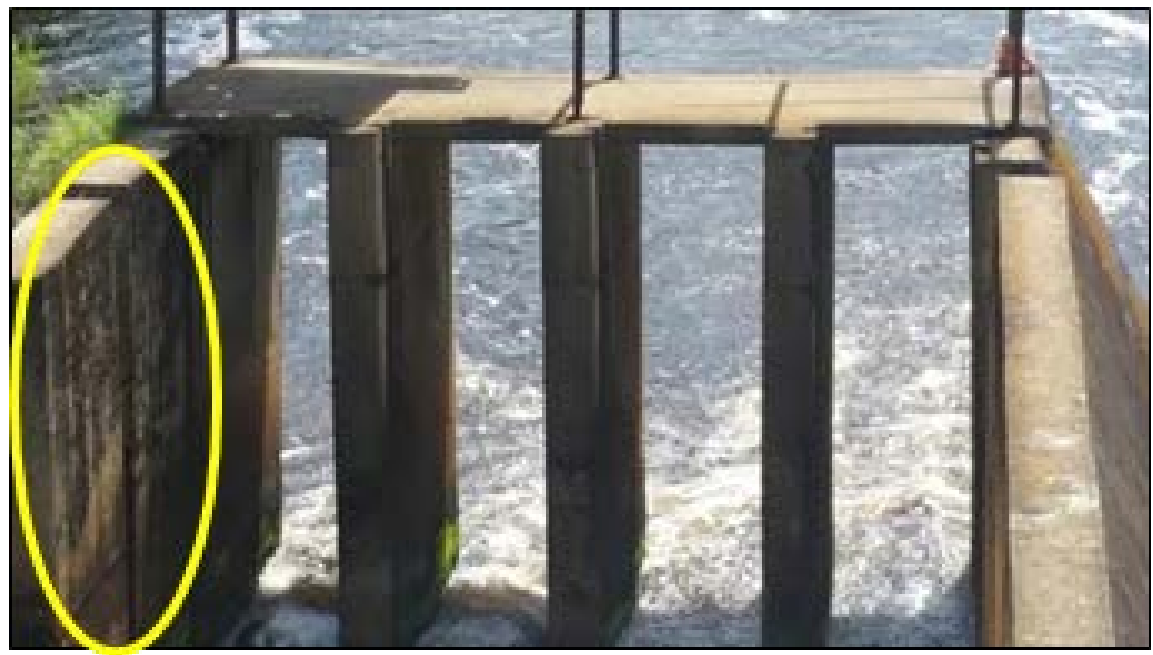

Figure 6. Downstream view of the restitution channel on the left side of the spillway [26]. 


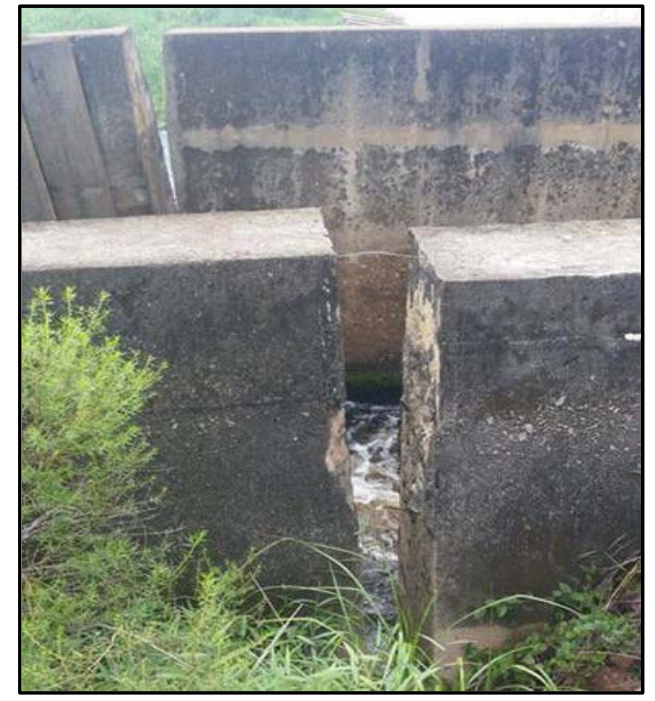

Figure 7. Detail of the rupture of the restitution channel on the left side of the spillway [26].

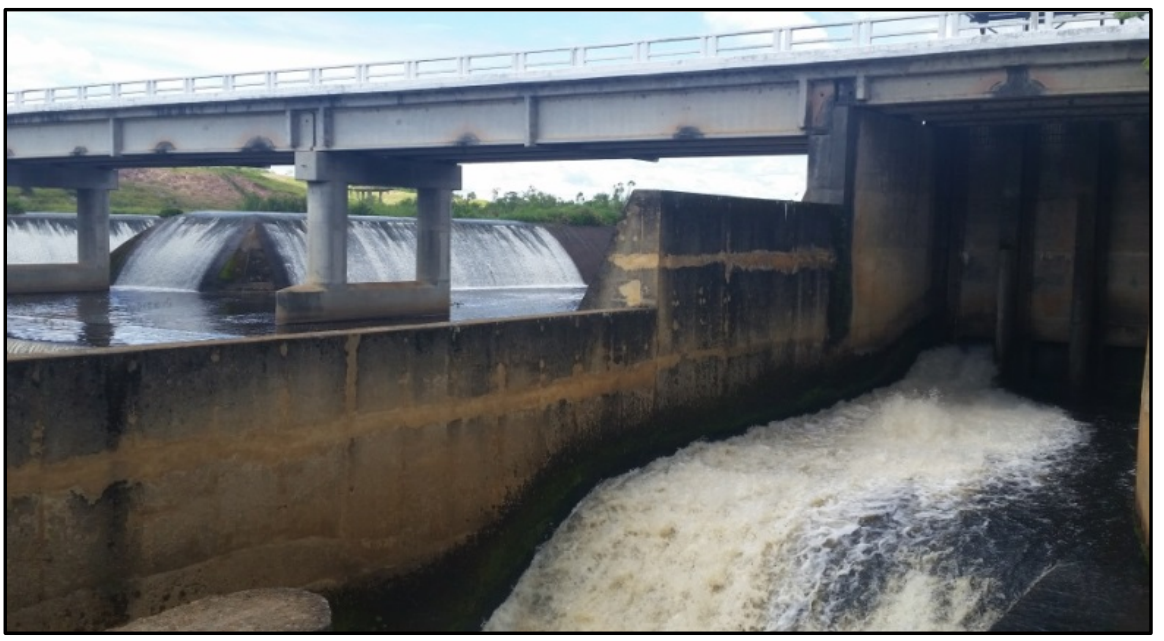

Figure 8. Rightmost floodgate of the left side with spillway detail in the background [26].

It was also found that 3 of the 4 sluices were closed with their respective floodgates and that only two protection grids were present to guard against floating material on the upstream wall, as shown in Figure 9. The operating sluice did not have a protection grid (detail).

The presence of vegetation was also observed in the spillway, indicative of the relevant siltation and sediment accumulation process in the reservoir, as well as the lack of maintenance of the hydraulic structures of the dam, as shown in Figure 10.

In the restitution channels on both sides of the spillway, grooves for the descent of the stop-logs panels were visible. However, the panels were not located in the grooves nor in any location near the observed location. Thus, if there is a problem or need for maintenance of the floodgates, water will flow through the dam restitution channels without any type of control. 


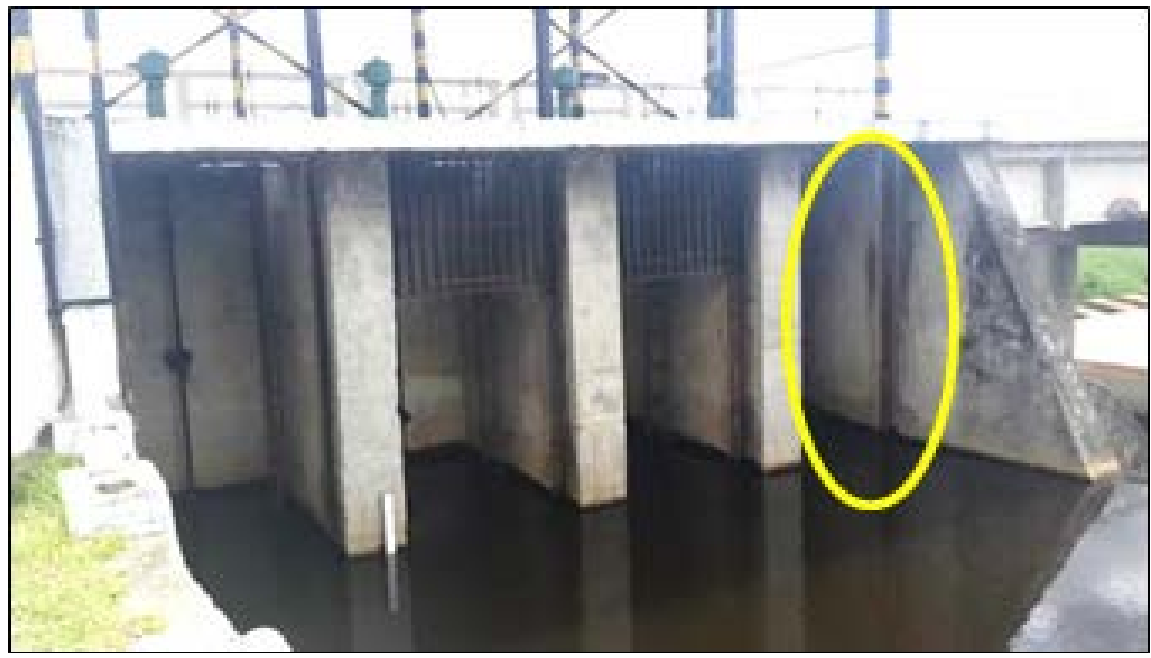

Figure 9. Detail for the grid of the upstream wall of the left side of the spillway [26].

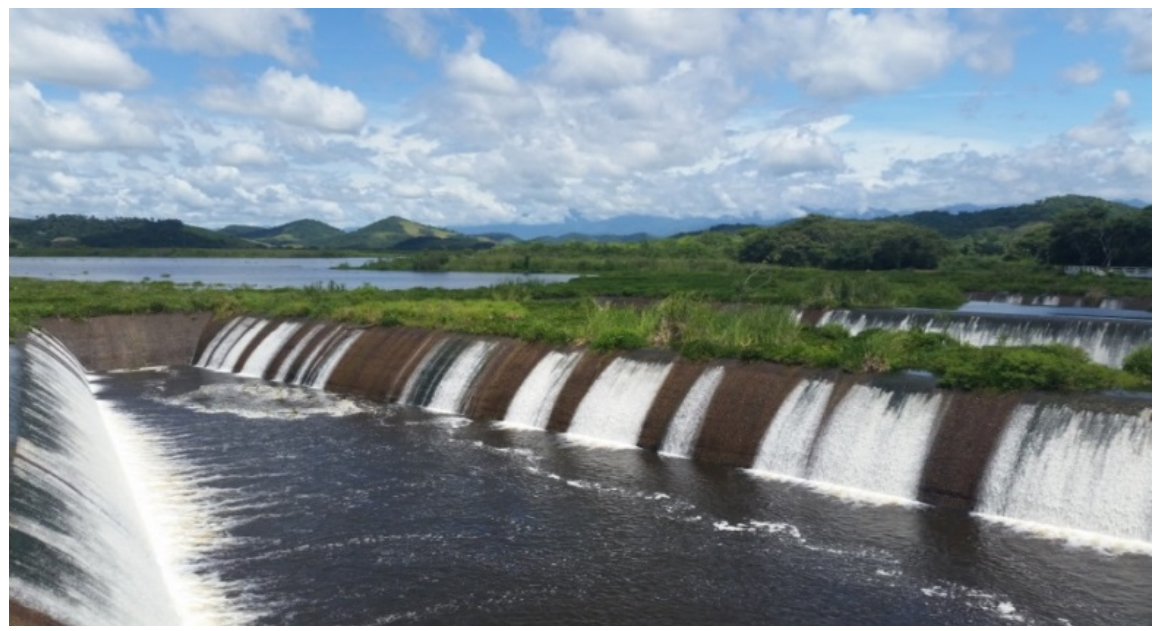

Figure 10. Presence of vegetation above the spillway [26].

Downstream of the spillway there are two sediment islands that have large amounts of vegetation, as shown Figure 11. These islands were probably formed by the sedimentation of the São João River banks and the transport of sediments and vegetation through the spillway.

\section{Results and Discussion}

Regarding the $\mathrm{CBDB}$ criteria listed in Tables 1-3, the Juturnaíba dam can be classified as high risk potential in terms of life and economic losses (Table 1) because there are extensive areas of agriculture and livestock downstream of the dam. Additionally, the 2nd district of Casimiro de Abreu, called Barra de São João, is at the mouth of the São João river and has a population of approximately 9000 inhabitants according to information from [27]. In the classification of the dam size (Table 2), the Juturnaíba site can be considered small in relation to height (5 to $15 \mathrm{~m}$ ) but large in relation to stored volume (above 50,000,000 $\mathrm{m}^{3}$ ). In the classification of spillway design (Table 3 ), the associated risk was 


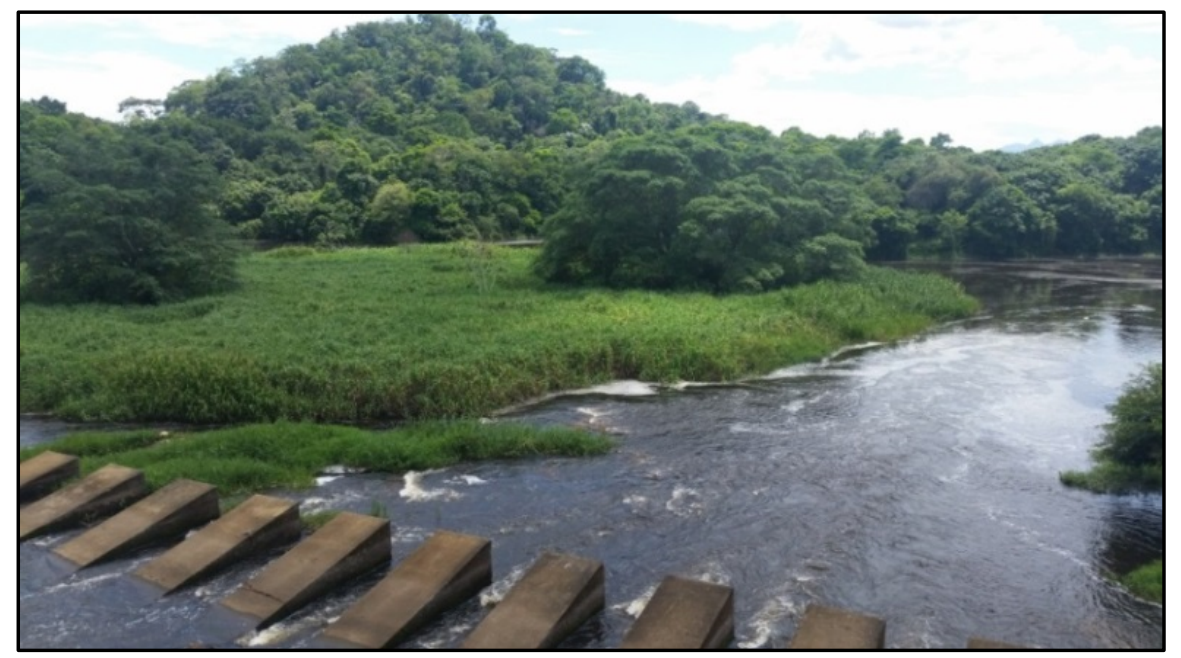

Figure 11. Islands of sediments downstream and close to the hydraulic structures of the dam [26].

considered high because the design flood should have a recurrence interval of 10,000 years (i.e., $1 \mathrm{PMF}$ ) regardless of the dam size being medium or large.

Tables 4-9 show the general criteria for the classification of dams by risk category, associated potential damage and reservoir volume, as established by resolution CNRH 143.

Regarding the technical characteristics (Table 4), the Juturnaíba dam achieves the following scores: height (0); length (3); type of dam as to building material (3); type of foundation (5); age of the dam (1); and design flow (3). It should be noted that the foundation soils in the region are predominantly soft clay, very soft clay and peat; however, in the classification considered in this study, there are no such distinctions. Thus, the worst condition (residual soil/alluvium) was considered, resulting in a total TC score of 15.

Regarding the state of conservation (Table 5), the site achieves the following scores: reliability of the overflow structures (10); reliability of adduction structures (6); percolation (3); deformations and settlements (1); deterioration of embankments/walls (5); and locks (0). In some places, access was not possible during the field visit; however, it was determined that no instrumentation is in operation based on information from the technicians responsible for inspection. Therefore, it is not possible to monitor displacements and pressures on the dam body. The sum of SC points was 25 .

Regarding the dam safety plan (Table 6), the site achieves the following scores: existence of documentation (4); organizational structure and technical qualification of the dam safety team (8); procedures for safety inspection and monitoring (5); operational rule of dam discharge devices (0); and safety inspection reports with analysis and interpretation (3). The total SP score was 20.

The final score of the risk category corresponds to the sum of the TC, SC and SP scores, and the result was 60 . It should be emphasized that if the $\mathrm{RC}$ is greater than or equal to 60 or if the SC score is greater than or equal to 8 in any analysis 
parameter, the dam is automatically classified as a high-risk category, requiring immediate action by the developer (Table 7). The Juturnaíba dam was thus classified as high risk.

Regarding the associated potential damage (Table 8), the site yielded the following score: total reservoir volume (3); potential loss of life (12); environmental impact (5); and socioeconomic impact (8). The total score for the APD resulted in 28 , which allows rating the dam as having high associated potential damage.

These results allow us to infer that by both the classification of the CBDB and the classification of Resolution CNRH 143, the risk potential associated with the Juturnaíba dam is high.

\section{Conclusions}

Both the potential and risk category of the Juturnaiba dam are high. Thus, due to the reservoir volume, potential human losses and environmental and socioeconomic impacts, potential damages can also be classified as high.

Efforts must be concentrated on defining prevention, mitigation, preparation, response and recovery actions, through the preparation and training of the Civil Defense teams of the surrounding municipalities, minimizing damage to the environment and to the populations located in the downstream valleys in the event of the dam rupture because overtopping is unlikely to occur.

In this study, no questions were raised about the integrity of the civil structures nor the geotechnical conditions of the dam mass. In view of the poor state of conservation of the site as ascertained during a field visit in January 2016, necessary interventions are urgently needed in addition to an assessment of the stability of the earth dam embankments.

Conducting interventions on degraded concrete structures and recovering or installing instruments to monitor the stability of the earth dam are also recommended.

\section{References}

[1] Mônica de Aquino Galeano da Hora, R. and Mônica de Aquino Galeano Massera da, H. (2016) Crise e escassez da água: A questão da segurança hídrica e a alternativa pela construção de barragens. In: I Congresso Brasileiro de Redução de Riscos de Desastres, 1., 2016, Curitiba: CEPED/PR, UNESPAR e UP, 1-7.

[2] ANA, Agência Nacional de Águas (2016) Relatório de segurança de barragens 2015. ANA, Brasília,186.

[3] Euclydes, C.J. (2014) Estudo de propagação de ondas em planície de inundação para elaboração de plano de ação emergencial de barragens: UHE Três Irmãos estudo de caso. 2014. 189 f. Dissertação (Mestrado em Recursos Hídricos)—Universidade Estadual Paulista, Faculdade de Engenharia de Ilha Solteira, Ilha Solteira, SP.

[4] Maria Teresa, V. and António Betâmio de, A. (2011) Gestão do risco nos vales a jusante de barragens. Territorium: Revista Portuguesa de riscos, prevenção e segurança, 18, 33-42.

[5] Rogério Moraes, N. and Jonatan Garrido, J. (2015) Aplicação das matrizes de classificação de risco e dano potencial associado da Lei 12.334 na UHE Itaúba-Rio Ja- 
cuí/RS. In: 15 Congresso Brasileiro de Geologia de Engenharia e Ambiental, 15, 2015, Bento Gonçalves. Anais... Bento Gonçalves: ABGE, 2015, 1-10. http://cbge2015.hospedagemdesites.ws/trabalhos/trabalhos/284.pdf

[6] Monica Resio, Z. (2005) Metodologia para avaliação da segurança de barragens. 2005. 207p. Dissertação (Mestrado em Engenharia Civil)_Universidade Estadual de Campinas, Faculdade de Engenharia Civil, Arquitetura e Urbanismo, Campinas, SP.

[7] Rio de Janeiro (Estado) (2015) Secretaria do Ambiente. Instituto Estadual do Ambiente. Relatório de Vistoria na barragem de Juturnaíba-RV 0003/15. Relatório. Rio de Janeiro, 20 de fevereiro de 2015, 6 .

[8] Rio de Janeiro (Estado) (2015) Secretaria do Ambiente. Instituto Estadual do Ambiente. Relatório de Vistoria conjunta na barragem de Juturnaíba-RVC 0010/15. Relatório. Rio de Janeiro, 16 de dezembro de 2015, 9.

[9] Eletrobras, Eletrobras Centrais Elétricas Brasileiras SA (1987) Guia para Cálculo de Cheia de Projeto de Vertedores. Manual. Rio de Janeiro: Diretoria de Planejamento e Engenharia, 294.

[10] Fontenelle, Alexandre de Sousa (2007) Proposta Metodológica de Avaliação de Riscos em Barragens do Nordeste Brasileiro-Estudo de Caso: Barragens do Estado do Ceará. Tese (Doutorado em Engenharia Civil)—Centro de Tecnologia, Universidade Federal do Ceará, Fortaleza, 214.

[11] ICOLD, International Commission On Large Dams (1995) Dam Failures Statistical Analysis. Bulletin, 99, 76.

[12] Brasil, Lei 12.334 (2010) Política Nacional de Segurança de Barragens. Presidência da República. Diário Oficial da União, No. 181, 21 set., Seção 1. Brasília, 2010, 1-3.

[13] Brasil, Resolução 143 (2012) Conselho Nacional de Recursos Hídricos. Diário Oficial da União, No. 172, 4 set., Seção 1. Brasília, 2012, 149-152.

[14] Gustavo Carneiro de, N. (2009) Avaliação hídrica do Lago de Juturnaíba como alternativa de abastecimento de água do Complexo Petroquímico do Rio de Janeiro-COMPERJ. Monografia (Especialização em Gestão Ambiental)-Laboratório de Tecnologia, Gestão em Negócios e Meio Ambiente, Universidade Federal Fluminense, Niterói, 64.

[15] WWF, World Wildlife Fund (2017) Case Study on River Management: São João. http://wwf.panda.org/about_our_earth/about_freshwater/rivers/irbm/cases/sao_joa o_river_case_study_cfm/

[16] COSTA Helder (1999) Subsídios para gestão dos recursos hídricos das bacias hidrográficas dos rios Macacu, São João, Macaé e Macabu. SEMA, Rio de Janeiro.

[17] CUNHA Sandra Baptista da (1995) Impactos das obras de engenharia sobre o ambiente biofísico da bacia do rio São João (Rio de Janeiro-Brasil). Tese, Doutorado em Geografia Física, Faculdade de Letras, Universidade de Lisboa, Lisboa, 415 p.

[18] ICMBio. Instituto Chico Mendes de Conservação da Biodiversidade. Unidades de Conservação Mata Atlântica. http://www.icmbio.gov.br/portal/rebio-de-poco-das-antas

[19] COHIDRO (2008) Serviços de Hidrometria nos rios São João, Capivari e Bacaxá-Levantamentos Batimétricos na Lagoa de Juturnaíba. Relatório. COHIDRO Consultoria, Estudos e Projetos Ltda, Rio de Janeiro.

[20] CRUZ Paulo Teixeira da (1983) A Barragem de Juturnaíba-Breve história com ilustrações. Relatório. Rio de Janeiro, 53 p, Cópia autenticada do Acervo do Arquivo Nacional. 
[21] Departamento Nacional de Obras de Saneamento (1979) Barragem de Juturnaíba-Modelo de Vertedouro em Zig-Zag-Planta-Seções-Detalhes. Desenho ${ }^{\circ}$ 3479, Proc. no 455 Escala 1:1000, Cópia do Acervo do Arquivo Nacional.

[22] Projetos e Consultorias de Engenharia Ltda (1997) Barragem e Reservatório de Juturnaíba-Investigações e estudos das condições de segurança e operacionaisManual de operação e manutenção, No PJ208-RTJUT03. Relatório. Rio de Janeiro, dezembro de, $23 \mathrm{p}$.

http://www.lagossaojoao.org.br/operacao_barragem_reservatorio_juturnaiba.pdf

[23] PROLAGOS (2016) Barragem de Juturnaíba-Relatório Final. Relatório. Rio de Janeiro, $81 \mathrm{p}$.

[24] BORGES (1991) José Bernardino. Análise do adensamento da fundação da barragem de Juturnaíba. Dissertação (Mestrado em Engenharia Civil) Instituto Alberto Luiz Coimbra de Pós-Graduação e Pesquisa de Engenharia, Universidade Federal do Rio de Janeiro, Rio de Janeiro, 173 p.

[25] Coutinho, R.Q. (1986) Aterro experimental instrumentado levado à ruptura sobre solos orgânicos-argilas moles da Barragem de Juturnaíba. Tese Doutorado em Engenharia Civil, Instituto Alberto Luiz Coimbra de Pós-Graduação e Pesquisa de Engenharia, Universidade Federal do Rio de Janeiro, Rio de Janeiro, 632 p.

[26] Rocha, Mônica de Aquino Galeano da Hora (2017) Avaliação do risco de galgamento pela passagem da cheia decamilenar sobre a Barragem de Juturnaíba, localizada na bacia do rio São João, estado do Rio de Janeiro. Dissertação, Mestrado em Defesa e Segurança Civil, Programa de Pós-graduação em Defesa e Segurança Civil, Universidade Federal Fluminense, Niterói, $125 f$.

[27] BARRA DE SÃO JOÃO. Informações sobre a cidade. http://www.barradesaojoao-rj.org/portugues/01_cidade/02_cidade/02_cidade.html 